\title{
THREE-DIMENSIONAL MAPPING OF EQUIPROBABLE HYDROSTRATIGRAPHIC UNITS AT THE FRENCHMAN FLAT CORRECTIVE ACTION UNIT, NEVADA TEST SITE
}

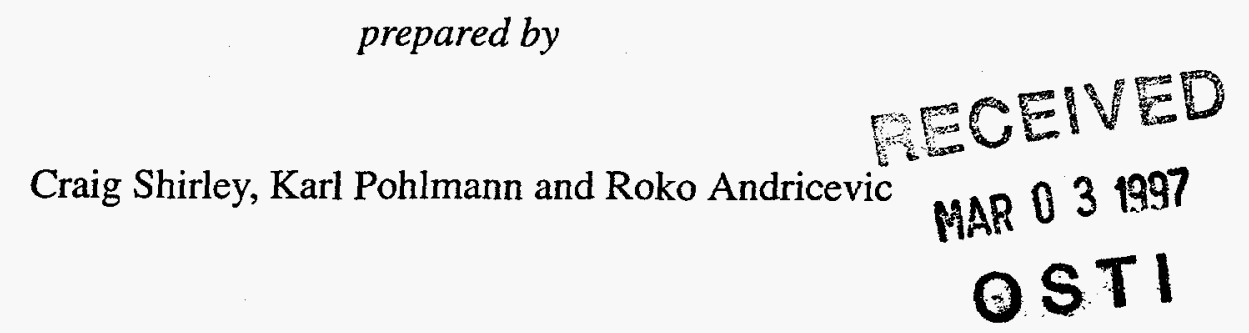

submitted to

Nevada Operations Office

U.S. Department of Energy

September 1996

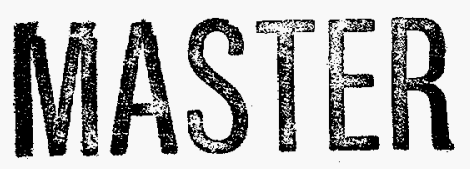

DISTRIBUTON OF THS DOCMENT IS IMTMARE 10

Publication No. 45152 


\section{DISCLAIMER}

Portions of this document may be illegible in electronic image products. Images are produced from the best available original document. 
This report was prepared as an account of work sponsored by the United States Government. Neither the United States nor the United States Department of Energy, nor any of their employees, makes any warranty, express or implied, or assumes any legal liability or responsibility for the accuracy, completeness or usefulness of any information, apparatus, product or process disclosed, or represents that its use would not infringe privately owned rights. Reference herein to any specific commercial product, process, or service by trade name, mark, manufacturer, or otherwise, does not necessarily constitute or imply its endorsement, recommendation, or favoring by the United States Government or any agency thereof. The views and opinions of authors expressed herein do not necessarily state or reflect those of the United States Government or any agency thereof.

This report has been reproduced directly from the best available copy.

Available to DOE and DOE contractors from the Office of Scientific and Technical Information, P.O. Box 62, Oak Ridge, TN 37831; prices available from (615) 576-8401.

Available to the public from the National Technical Information Service, U.S. Department of Commerce, 5285 Port Royal Rd., Springfield, VA 22161. 


\title{
THREE-DIMENSIONAL MAPPING OF EQUIPROBABLE HYDROSTRATIGRAPHIC UNITS AT THE FRENCHMAN FLAT CORRECTIVE ACTION UNIT, NEVADA TEST SITE
}

\author{
prepared by \\ Craig Shirley, Karl Pohlmann and Roko Andricevic \\ Water Resources Center \\ Desert Research Institute \\ University and Community College System of Nevada
}

Publication No. 45152

submitted to

Nevada Operations Office

U.S. Department of Energy

Las Vegas, Nevada

September 1996

The work upon which this report is based was supported by the U.S. Department of Energy under Contract \#DE-AC08-95NV11508. 


\begin{abstract}
Geological and geophysical data are used with the sequential indicator simulation algorithm of Gomez-Hernandez and Srivastava (1990) to produce multiple, equiprobable, three-dimensional maps of informal hydrostratigraphic units at the Frenchman Flat Corrective Action Unit, Nevada Test Site. The upper 50 percent of the Tertiary volcanic lithostratigraphic column comprises the study volume. Semivariograms are modeled from indicator-transformed geophysical tool signals. Each equiprobable study volume is subdivided into discrete classes using the ISIM3D implementation of the sequential indicator simulation algorithm. Hydraulic conductivity is assigned within each class using the sequential Gaussian simulation method of Deutsch and Journel (1992). The resulting maps show the contiguity of high and low hydraulic conductivity regions.
\end{abstract}




\section{CONTENTS}

ABSTRACT $\ldots \ldots \ldots \ldots \ldots \ldots \ldots \ldots \ldots \ldots \ldots \ldots \ldots \ldots \ldots \ldots \ldots \ldots \ldots \ldots$

FIGURES $\ldots \ldots \ldots \ldots \ldots \ldots \ldots \ldots \ldots \ldots \ldots \ldots \ldots \ldots \ldots \ldots \ldots \ldots \ldots \ldots \ldots$ iii

TABLES $\ldots \ldots \ldots \ldots \ldots \ldots \ldots \ldots \ldots \ldots \ldots \ldots \ldots \ldots \ldots \ldots \ldots \ldots \ldots \ldots \ldots \ldots$

INTRODUCTION $\ldots \ldots \ldots \ldots \ldots \ldots \ldots \ldots \ldots \ldots \ldots \ldots \ldots \ldots \ldots \ldots \ldots \ldots$

GEOLOGIC SETTING $\ldots \ldots \ldots \ldots \ldots \ldots \ldots \ldots \ldots \ldots \ldots \ldots \ldots \ldots \ldots$

HYDROGEOLOGIC SETTING $\ldots \ldots \ldots \ldots \ldots \ldots \ldots \ldots \ldots \ldots \ldots \ldots \ldots \ldots$

METHOD $\ldots \ldots \ldots \ldots \ldots \ldots \ldots \ldots \ldots \ldots \ldots \ldots \ldots \ldots \ldots \ldots \ldots \ldots \ldots$

RESULTS AND DISCUSSION $\ldots \ldots \ldots \ldots \ldots \ldots \ldots \ldots \ldots \ldots \ldots \ldots \ldots \ldots \ldots$

REFERENCES $\ldots \ldots \ldots \ldots \ldots \ldots \ldots \ldots \ldots \ldots \ldots \ldots \ldots \ldots \ldots \ldots \ldots \ldots$ 


\section{FIGURES}

1. Frenchman Flat Corrective Action Unit (CAU) location map. . . . . . . . . 2

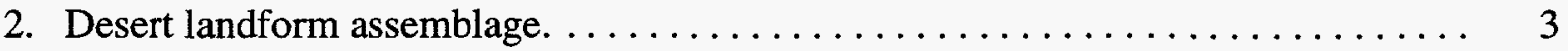

3. Boreholes and underground nuclear tests, Frenchman Flat, NTS. . . . . . . . 4

4. Generalized lithostratigraphic column for the Frenchman Flat CAU. . . . . . . 5

5. Contoured geologic contacts at the Frenchman Flat CAU. ........... 6

6. Short normal, long normal, $18 \mathrm{ft} 8$ in lateral, and induction tool resistivity curves. . 10

7. Scatterplot and regression line for resistivity measured by the long normal and $18 \mathrm{ft} 8$ in lateral tools.

8. Vertical experimental semivariograms for Frenchman Flat resistivity data at three thresholds.

9. Realizations $\mathrm{AA}$ and $\mathrm{AB}$ of the welded tuff.

10. Realizations $\mathrm{AC}$ and $\mathrm{AD}$ of the welded tuff.

11. Realizations $\mathrm{AA}$ and $\mathrm{AB}$ of hydraulic conductivity equal to or greater than $2.0 \mathrm{~m} /$ day.

12. Realizations $A C$ and $A D$ of hydraulic conductivity equal to or greater than $2.0 \mathrm{~m} /$ day.

\section{TABLES}

1. Underground nuclear tests conducted within the northern portion of the Frenchman Flat CAU. 


\section{INTRODUCTION}

The objective of this study was development of a three-dimensional representation of the hydrostratigraphy of the Frenchman Flat Corrective Action Unit (CAU), Nevada Test Site (NTS). Hydrostratigraphic units are "... defined and recognized by observable characteristics of the interstices in any body of rock. They are defined by the number, size, shape, arrangement, and interconnection of the interstices, and are recognized on the basis of the nature, extent and magnitude of the interstices in any body of sedimentary, metamorphic, or igneous rock" (Seaber, 1992). Hydrostratigraphic units represent the relationship between the rock column, i.e., the lithostratigraphy, and the spatial occurrence of hydrologically significant pore geometry. Hydrostratigraphic units may coincide with lithostratigraphic units, may be a part of a single lithostratigraphic unit, or may cut across multiple lithostratigraphic units.

The study uses a procedure for generating equiprobable maps of subsurface heterogeneity that incorporates all available data while retaining the connectivity patterns of zones of high hydraulic conductivity. The indicator formalism (Journel, 1989; Journel and Alabert, 1990) which allows the interpretive information to be coded into elementary bits (valued at zero or one) is followed. These bits are then processed independently of origin, be it hard or soft data ${ }^{1}$, to generate subsurface maps of the hydrostratigraphic units. The study uses a methodology described by Pohlmannn and Andricevic (1994) whereby selected geophysical logs whose signals demonstrate a relationship to a particular hydrogeologic attribute (e.g., porosity, permeability) are used as soft data. The continuous range of geophysical signal is divided into classes, each of which represents a category of the hydrogeologic attribute. These classes then represent the elementary bits used in the indicator simulations.

This report describes the methodology as it was applied to generate three-dimensional maps of the hydrostratigraphic units at the Frenchman Flat CAU.

\section{GEOLOGIC SETTING}

Frenchman Flat (Figure 1) is an alluvium-filled, closed basin, elongated along the northeast-southwest axis, displaying the classic desert landforms illustrated in Figure 2. The basin is bounded on the south and east by the Ranger Mountains and Mercury Ridge outcrops and on the west by the Hampel Hill-Mount Sayler High (Miller and Healy, 1986). The study area, shown in Figure 3, is a rectangle $2600 \mathrm{~m}$ east to west and $2200 \mathrm{~m}$ north to south, containing 33 boreholes, ranging in depth from 397 to $784 \mathrm{~m}$. Table 1 lists the seven underground nuclear tests that have been conducted in the study area, which covers the northern portion of the CAU. The alluvial valley fill ranges in thickness from $58 \mathrm{~m}$ at the northern edge of the study area to $506 \mathrm{~m}$ at the southeastern corner. Six of the seven tests were conducted in the alluvial fill, between 65 and $247 \mathrm{~m}$ above the alluvium-tuff contact. The seventh test, U11b, was conducted within the volcanic tuff section, approximately $240 \mathrm{~m}$ below the alluvium contact.

\footnotetext{
${ }^{1}$ Hard data are measurements of the property of interest; soft data are measurements or estimates of properties which show a relationship to the property of interest.
} 


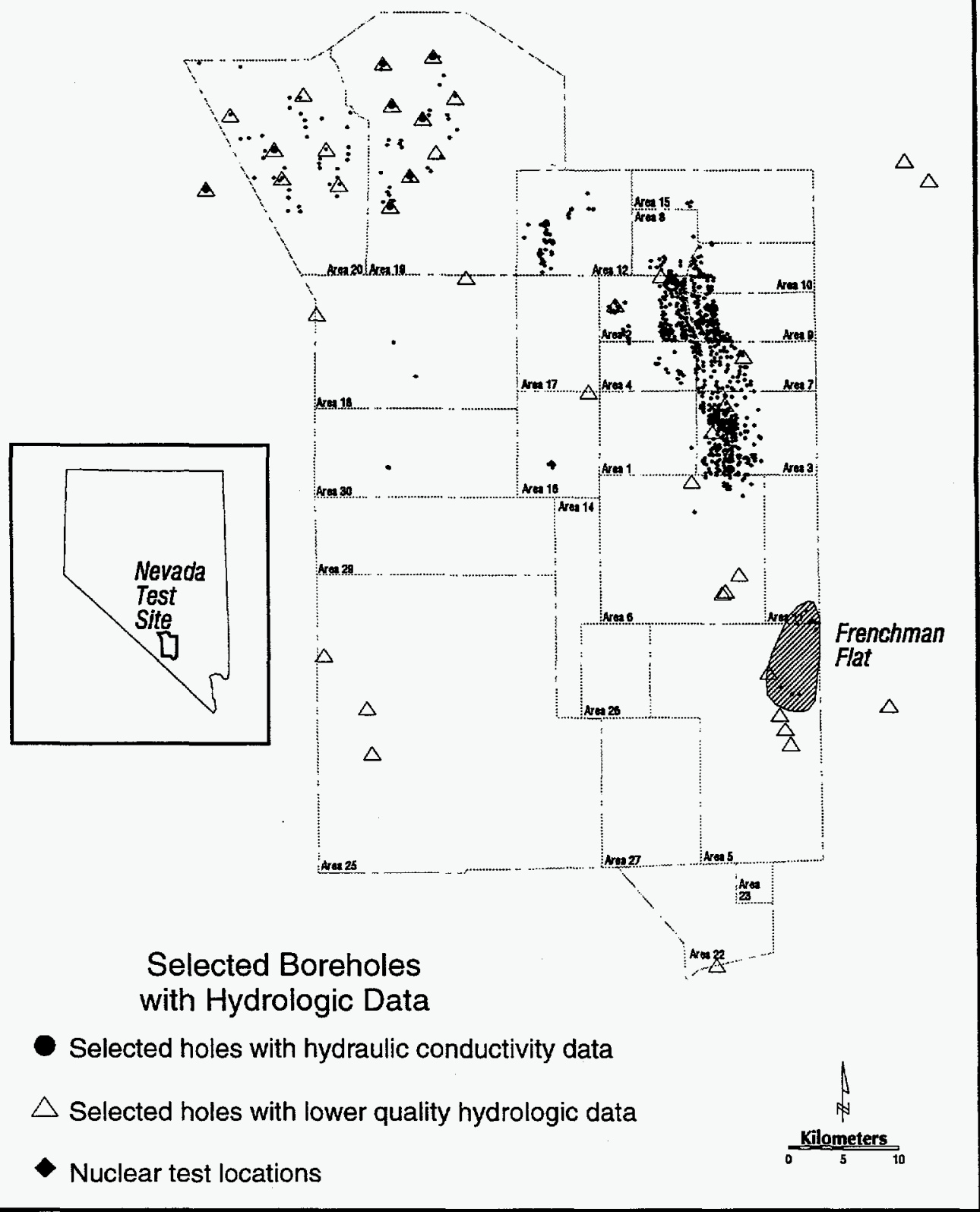

Figure 1. Frenchman Flat Corrective Action Unit (CAU) location map.

Underlying the alluvium is a sequence of Tertiary volcanics estimated to range in thickness from under $500 \mathrm{~m}$ at the northern edge of the study area to over $700 \mathrm{~m}$ at the southern edge. The Frenchman Flat study area penetrated by drilling shows considerable geologic similarity with the more intensively investigated Yucca Flat, lying directly to the north (Shirley, 1995; Pohlmannn and Andricevic, 1994). Surficial alluvium derived from the surrounding uplands overlays a thick sequence of Tertiary-age volcanic tuffs. Carbonates are believed to underlie the volcanic sequence, but none of the boreholes in the study area are deep enough to reach this contact (Miller and Healy, 


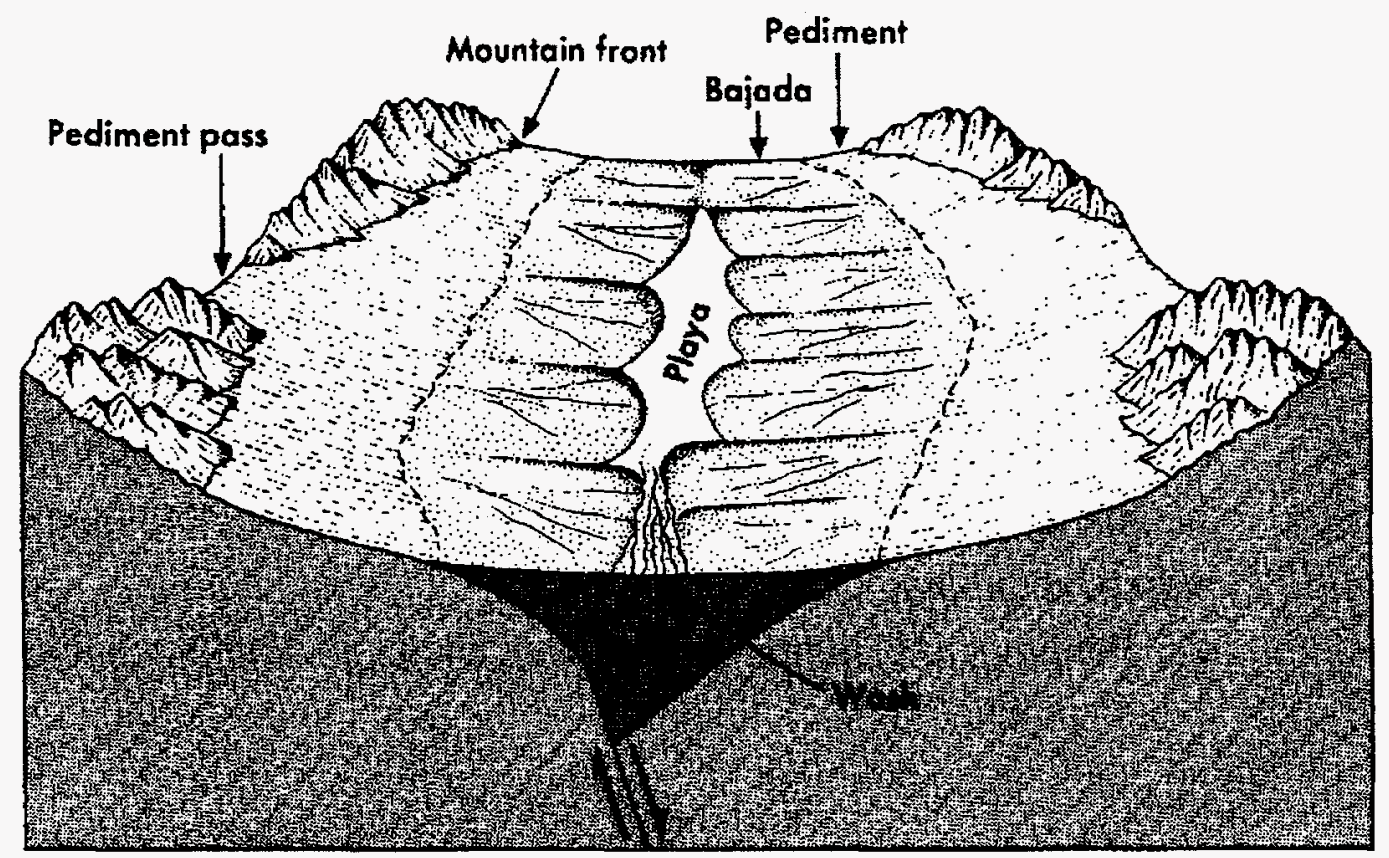

Figure 2. Desert landform assemblage, from Bloom, 1969, p. 75.

1986). Figure 4 is a generalized lithostratigraphic column for the study area. Not shown on the column is a thin $(20 \mathrm{~m})$ basalt layer, known as the Basalt of Frenchman Flat. This basalt, dated at 8.6 million years (Ma) by Crowe and Perry (1991), is found only in boreholes UE-5i and UE-5k, near the base of the alluvium. Outcrops of basalts are found north and east of the study area. The Basalt of Scarp Canyon, dated at 8.7 Ma by Christiansen and Lipman (1972), is the oldest and nearest to the study area. The Basalt of Paiute Ridge, dated at $8.5 \mathrm{Ma}$ by Crowe et al. (1986), is the farthest to the north. The Basalt of Nye Canyon, dated at $6.5 \mathrm{Ma}$ by Crowe (1990), is farthest to the east of the study area.

TABLE 1. UNDERGROUND NUCLEAR TESTS CONDUCTED WITHIN THE NORTHERN PORTION OF THE FRENCHMAN FLAT CAU.

\begin{tabular}{cclcl}
\hline Date & Hole Name & Test Name & Depth of Burial (m) & Geologic Unit \\
\hline $4 / 25 / 66$ & U11b & PIN STRIP & 296 & Volcanic Tuff \\
$9 / 12 / 66$ & U5i & DERRINGER & 256 & Alluvium \\
$12 / 13 / 66$ & U11c & NEW POINT & 239 & Alluvium \\
$3 / 25 / 68$ & U5k & MILK SHAKE & 265 & Alluvium \\
$8 / 27 / 68$ & U11e & DIANA MOON & 241 & Alluvium \\
$9 / 12 / 69$ & U11f & MINUTE STEAK & 265 & Alluvium \\
$11 / 24 / 71$ & U11g & DIAGONAL LINE & 267 & Alluvium \\
\hline
\end{tabular}




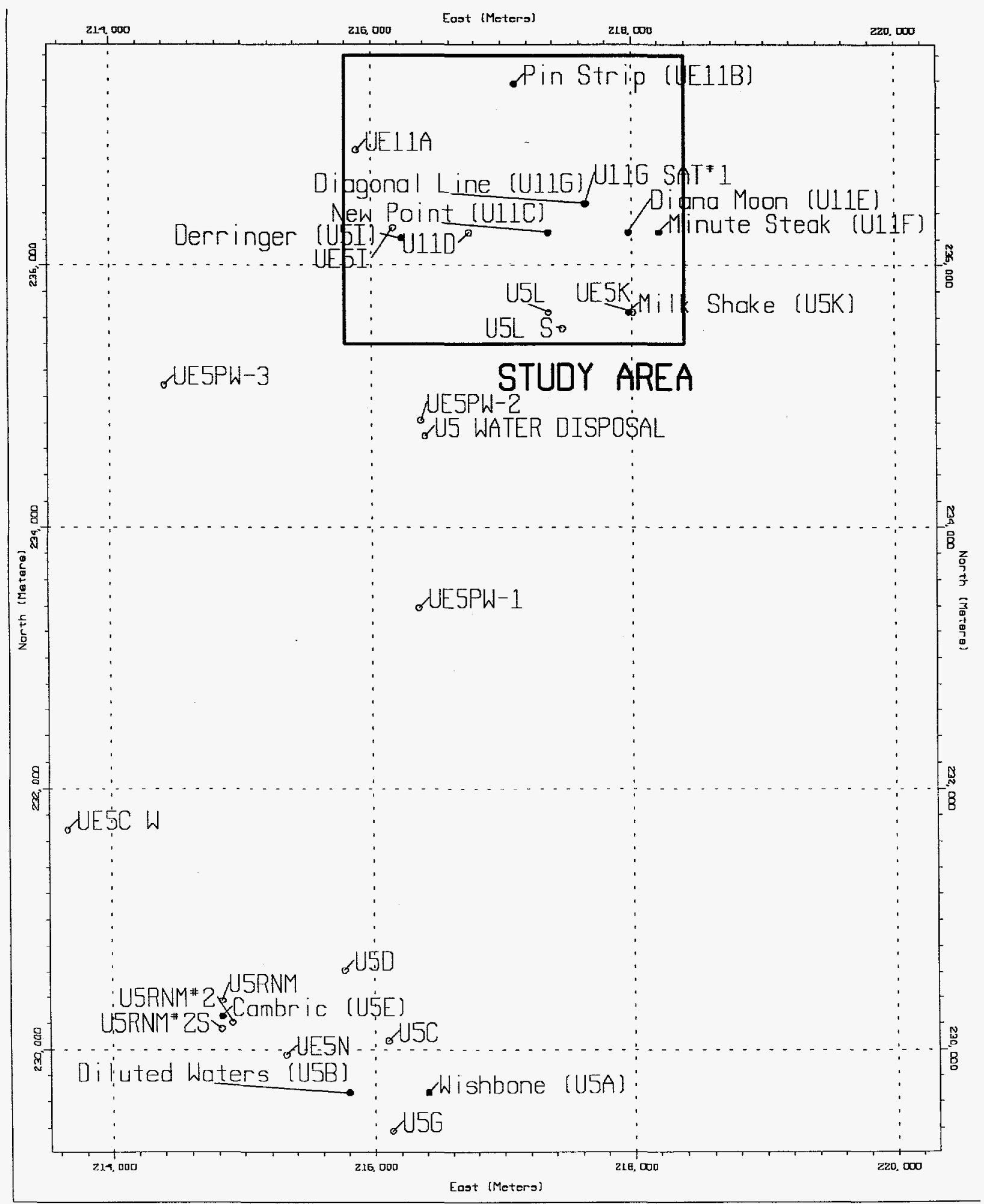

Figure 3. Boreholes and underground nuclear tests, Frenchman Flat, NTS. 


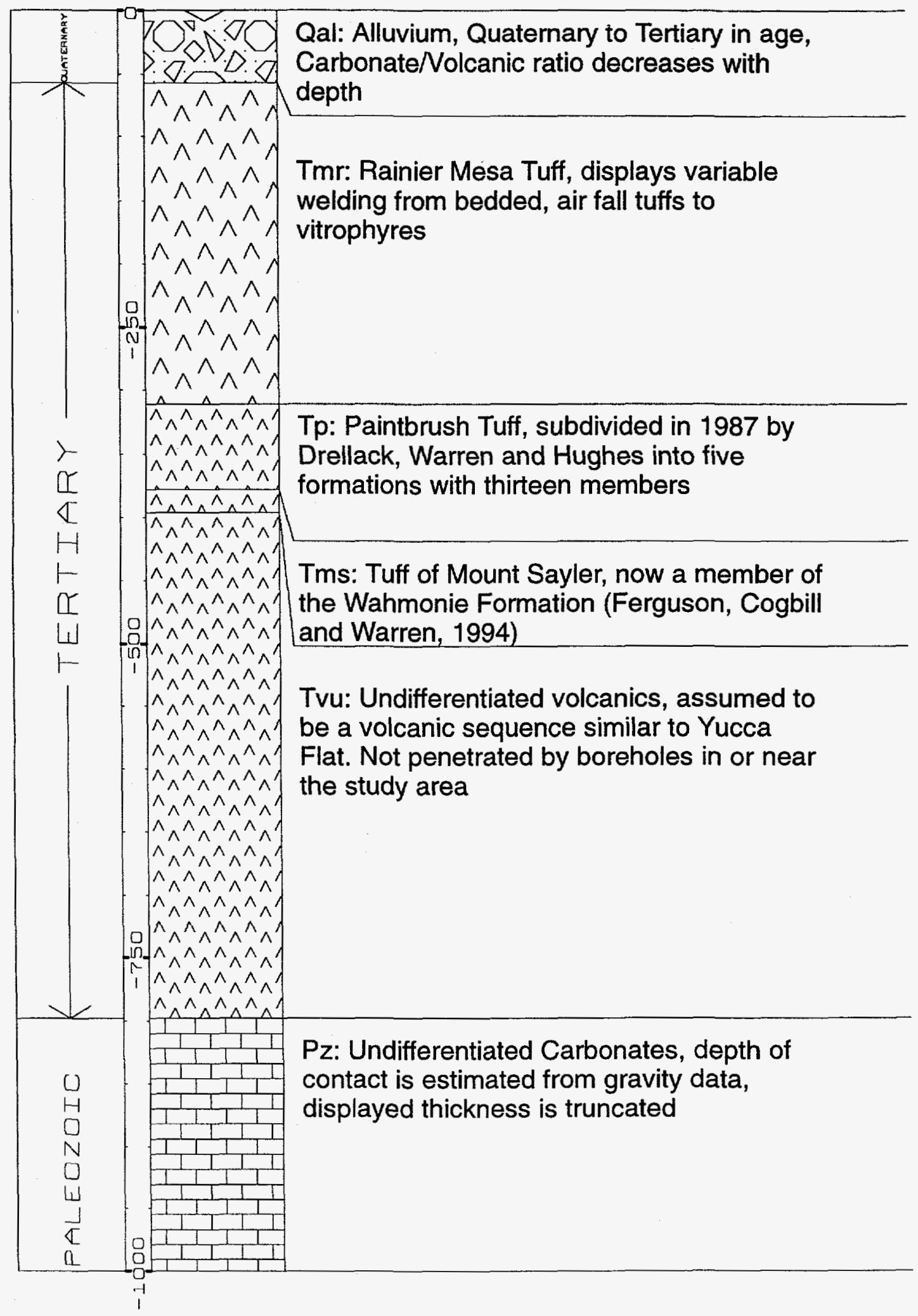

Figure 4. Generalized lithostratigraphic column for the Frenchman Flat CAU. 
The modeled domain is a roughly tabular body of volcanic rock dipping to the south (Figure 5). The overlying alluvial wedge thickens $450 \mathrm{~m}$ in the $2200 \mathrm{~m}$ of north-south distance covered by the study area. Volcanic rocks are exposed immediately to the north of the study area. Paleozoic rocks are exposed in an outcrop approximately $10,000 \mathrm{~m}$ to the northeast of the study area. All of these observations and measurements are consistent with an extensional basin edge filled with detritus shed from the surrounding uplands.

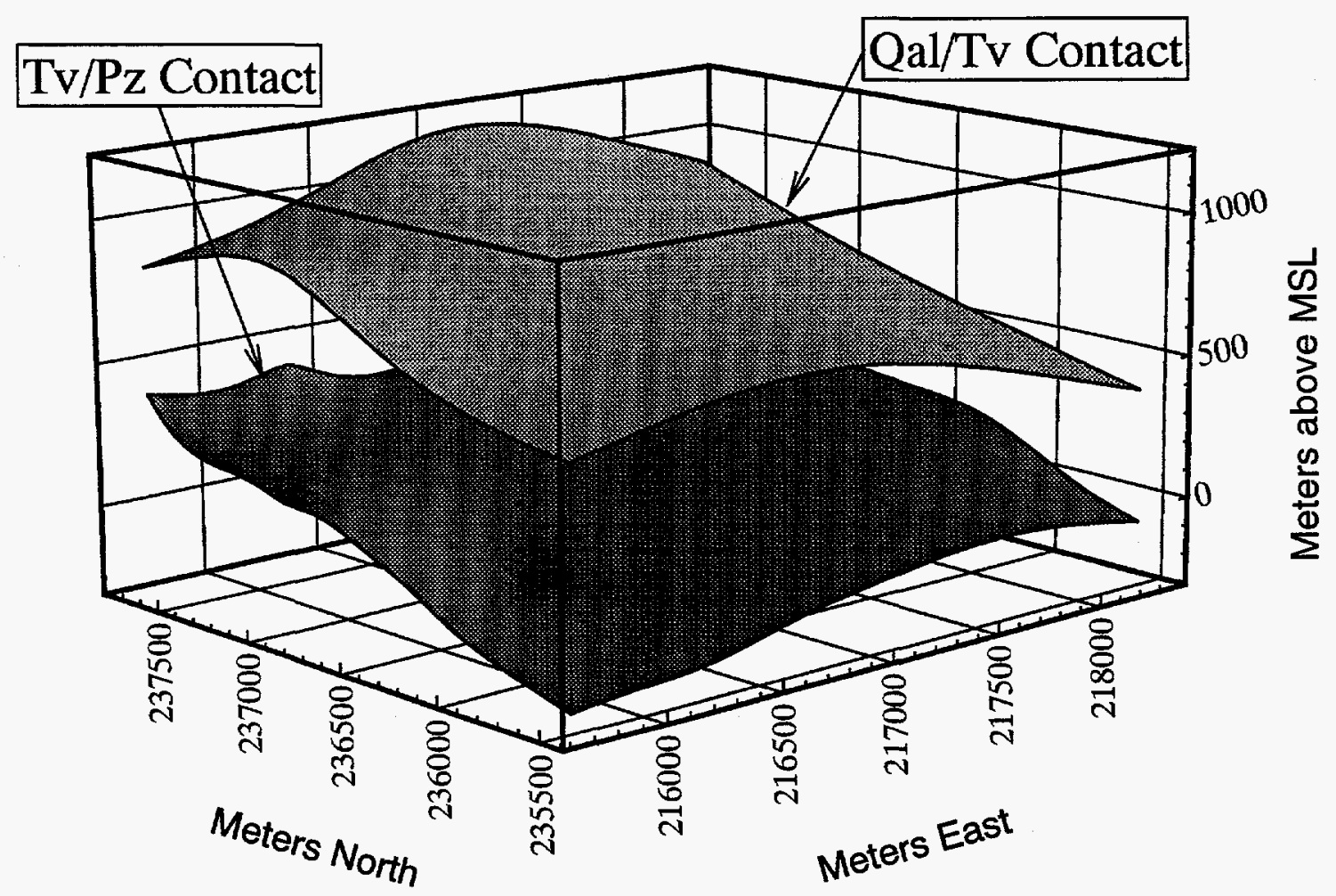

Figure 5. Contoured geologic contacts at the Frenchman Flat CAU.

\section{HYDROGEOLOGIC SETTING}

Winograd and Thordarson (1975) classified the hydrogeologic units on and near the NTS into ten principal units. Of these, four are important to groundwater flow below Frenchman Flat. They are the lower carbonate aquifer, tuff aquitard, welded-tuff aquifer, and valley-fill aquifer. The following summary is based primarily on Winograd and Thordarson's work.

The lower carbonate aquifer is composed of Middle Cambrian through Devonian carbonate rocks and reaches a saturated thickness of $1000 \mathrm{~m}$ or more. The porosity and hydraulic conductivity of the carbonate matrix are both very low, so fractures provide the means for most groundwater flow in the unit. Although the fracture frequency is widely variant, overall fracture conductivity is high enough that the carbonate aquifer is one of the most transmissive on the NTS; the IT/GeoTrans database reports a range of hydraulic conductivity to be 0.09 to $731 \mathrm{~m} / \mathrm{d}$ based on 17 measurements 
on the NTS (Rehfeldt et al., 1995). The lower carbonate aquifer, which provides for most of the interbasin flow in the regional aquifer system, appears to underlie most of Frenchman Flat.

The tuff aquitard consists primarily of non-welded to partially welded ash-flow tuff and ash-fall tuff of Tertiary age. Other rocks included in this unit are tuff breccia, breccia flow, tuffaceous sandstone, siltstone, mudstone, freshwater limestone, and minor densely welded tuff, all of Tertiary age. The tuffs in this unit exhibit high interstitial porosity but very low interstitial hydraulic conductivity because most of their pores are unconnected and because they are composed of zeolites or clay minerals. In addition, since fractures and faults in this friable, non-welded unit do not remain open and available for groundwater flow, overall hydraulic conductivity is very low. The tuff aquitard is as much as $1375 \mathrm{~m}$ thick below Frenchman Flat and separates the valley-fill and welded-tuff aquifers from the underlying lower carbonate aquifer.

The welded-tuff aquifer is composed of late Miocene and Pliocene non-welded to densely welded ash-flow tuff, with minor amounts of ash-fall tuff. Interstitial porosity is inversely related to the degree of welding; non-welded tuff may exhibit interstitial porosity greater than 0.50 , while the interstitial porosity of densely welded tuff is generally less than 0.05 . Non-welded tuffs in the welded-tuff aquifer have very low hydraulic conductivity for the reasons previously mentioned. However, the densely welded ash-flow tuffs, which have very low interstitial porosity and hydraulic conductivity, tend to be brittle, which aids in the formation of joints and fractures. These features tend to remain open after formation and therefore represent important pathways for groundwater flow. The IT/GeoTrans database reports a range of hydraulic conductivity for the welded tuff aquifer to be 0.09 to $1.71 \mathrm{~m} / \mathrm{d}$ based on seven measurements on the NTS (Rehfeldt et al., 1995). The welded-tuff aquifer is present in the structurally deepest parts of Frenchman Flat; at the margins, it is generally situated above the water table.

The valley-fill aquifer is characterized by alluvial-fan, fluvial, fanglomerate, lakebed, and mudflow deposits in depressions created by post-Pliocene block faulting. Interstitial porosities of over 200 core samples collected from boreholes in northern Frenchman Flat were generally greater than 0.30 (Reynolds Electrical and Engineering Co., 1993a and 1993b). Hydraulic conductivity ranges from 0.30 to $41 \mathrm{~m} / \mathrm{d}$ based on 14 measurements on the NTS (Rehfeldt et al., 1995). The valley-fill aquifer is present in the central, structurally deepest portion of Frenchman Flat, where the valley-fill/volcanic-tuff contact is lower than the water table. Six of the seven nuclear tests within the study area were conducted in the valley-fill and all of them were conducted above the water table (22 to $64 \mathrm{~m})$.

Water-level data in the valley are limited but the available evidence suggests that semi-perched conditions occur between the valley-fill aquifer and the lower carbonate aquifer. Horizontal gradients in the valley-fill of northern Frenchman Flat appear to be very low (approximately 3.0e-4). The evidence implies internal drainage in response to the net downward hydraulic gradient and lack of significant horizontal gradients between Frenchman Flat and adjacent valleys. Therefore, groundwater in the valley-fill aquifer must pass through the welded-tuff aquifer and tuff aquitard before reaching the regional lower carbonate aquifer. 


\section{METHOD}

The resistivity $\log$ is commonly run at the NTS and is useful for evaluating certain hydrogeologic variables in the volcanic units (Pohlmann and Andricevic, 1994). For the purposes of this study, resistivity logs were evaluated primarily on their response to rock porosity. Because we are most interested in delineating connected groundwater flowpaths, the effective porosity is the most important form of porosity to consider.

Drellack (1994) describes the relation of resistivity log response to NTS volcanic geology, and the following summary is based on that work. Air-fall and non-welded ash-flow tuffs have high porosity and therefore exhibit low resistivity. As the degree of welding increases, porosity declines and the apparent resistivity increases. Densely welded tuffs and rhyolite lava flows have the highest resistivities. Wood and Fernandez (1988) point out "... in welded tuffs the center section with its large number of cooling fractures stores and transmits the greater quantity of water." Zeolitization and argillation results in lowering apparent resistivity in all tuffs because the presence of these minerals serves to reduce the resistivity of the rock matrix. Zones of alteration may also exhibit low apparent resistivity because the pore water is more conductive. As a result of these relationships, a high resistivity response is likely to indicate a densely welded tuff and a potential pathway for groundwater flow, while a low response is likely to indicate other volcanic rocks, which generally represent potential barriers to groundwater flow. For example, Blankennagel and Weir (1973) used resistivity logs to differentiate permeable densely welded tuffs and vitrophyres from relatively impermeable zeolitized tuffs on Pahute Mesa. They used a threshold resistivity value of 225 ohms $-\mathrm{m}^{2} / \mathrm{m}$. Drellack (1994) indicates that moderately to densely welded tuffs exhibit apparent resistivity of 200 to over $1000 \mathrm{ohms}-\mathrm{m}^{2} / \mathrm{m}$. Shirley (1995) concluded that apparent resistivity exceeding $300 \mathrm{ohms}-\mathrm{m}^{2} / \mathrm{m}$ is a good geophysical indicator of densely welded tuffs.

Geophysical log data were obtained from the NTS logging library. The logs were old enough that the data were available only as tracks on paper. These paper logs were sent to Cannon Digital Services and the tracks were digitally sampled on a $0.1525-\mathrm{m}(0.5-\mathrm{ft})$ interval. A total of 381 tracks in 15 holes were digitized. Examination of the data revealed that resistivity measurements were the most abundant, and best covered the depth interval of interest.

Four different tools were used to collect resistivity data: short (16 in) normal, long (64 in) normal, $18 \mathrm{ft} 8$ in lateral, and induction. The first three tools are restricted to uncased, fluid-filled boreholes, while the induction tool can operate in wet or dry, cased or uncased boreholes. The short normal, long normal and $18 \mathrm{ft} 8$ in lateral tools have electrodes separated vertically by increasing distance. The resistivity measured represents an integrated volume proportional to the electrode spacing. In general, the greater the electrode spacing, the greater the depth of investigation into the surrounding rock and the lower the vertical resolution (Schlumberger, 1989).

The induction tool uses alternating current and a transmitter loop to induce coaxial currents in the surrounding rock, which in turn induce current in a receiver loop. The tool measures the conductivity of the formation, which is inversely proportional to the resistivity (Collier, 1993). 
The $18 \mathrm{ft} 8$ in lateral tool signal (labeled, "Frenchman Flat Reference," in Figure 6) was selected as the reference datum, since it was the most common type of data and gives the greatest depth of investigation into the surrounding rock. The short normal, long normal and $18 \mathrm{ft} 8$ in lateral tools yield differing but strongly correlated ( $r=0.80$ to 0.91 ) measures of resistivity when run in the same borehole interval. Least squares regression lines were fit between measurements from the $18 \mathrm{ft} 8$ in lateral reference tool and the other resistivity tools, as illustrated by Figure 7 for the long normal tool. Short normal, long normal and induction resistivity log data were rescaled to correspond to the $18 \mathrm{ft} 8$ in lateral $\log$. This procedure was used to combine the intervals logged with differing resistivity tools into a dataset covering as much of the study area as possible. The dataset used for the geostatistical analysis was composed of 5,991 resistivity measurements located in three-dimensional space.

Vertical coordinates within the volcanic section were transformed from meters above mean sea level to stratigraphic elevation, $E_{s}$, as follows:

$$
E_{s}=\left(E_{m s l}-E_{V t / P z}\right) /\left(E_{Q a l} / / t-E_{V t / P z}\right)
$$

where $\quad E_{\mathrm{msl}}$ is the elevation of the point of interest, $\mathrm{E}_{\mathrm{Vt} / \mathrm{Pz}}$ is the elevation of the Tertiary volcanic/Paleozoic contact, and $\mathrm{E}_{\mathrm{Qa} / \mathrm{Vt}}$ is the elevation of the Quaternary alluvium/Tertiary volcanic contact.

Different procedures were used to develop the Tertiary volcanic/Paleozoic contact for Frenchman Flat and Yucca Flat. For Frenchman Flat, the Tertiary volcanic/Paleozoic contact was developed from gravity data published in Miller and Healy (1986). The study area was superimposed on the structural contour map, Figure 4-3 of the cited report, and coordinates of contours at the boundaries and interior points extracted. A minimum curvature surface was fit to these points and the elevation of the Tertiary volcanic/Paleozoic contact at borehole locations was then bilinearly interpolated using the method described in Press et al. (1989, pg 107-108.)

In Yucca Flat, the much greater density of boreholes penetrating the Tertiary volcanic/Paleozoic contact allowed the contouring of the Paleozoic surface using a minimum curvature algorithm. At borehole locations, the Tertiary volcanic/Paleozoic contact elevation was bilinearly interpolated for shallow holes from the surrounding grid points generated in the previous step.

Transforming spatial coordinates from elevation above mean sea level to stratigraphic elevation implies that the volume under investigation can be considered tabular. As show in Figure 5 , the volcanic section in the study area is a roughly tabular but not level body, showing considerable dip to the south. At least three geologically plausible explanations exist: 1) the volcanics may have been deposited on a sloping erosional or tectonic surface, 2) the volcanics and underlying Paleozoic sediments may have rotated or been warped as a block, or 3) high angle faults may exist between boreholes. If such faults do exist, then the surface shown in Figure 5 is incorrect. However, as Synder et al. (1994) state, "The occurrence of the basalt [of Frenchman Flat] at a similar depth in drillholes 


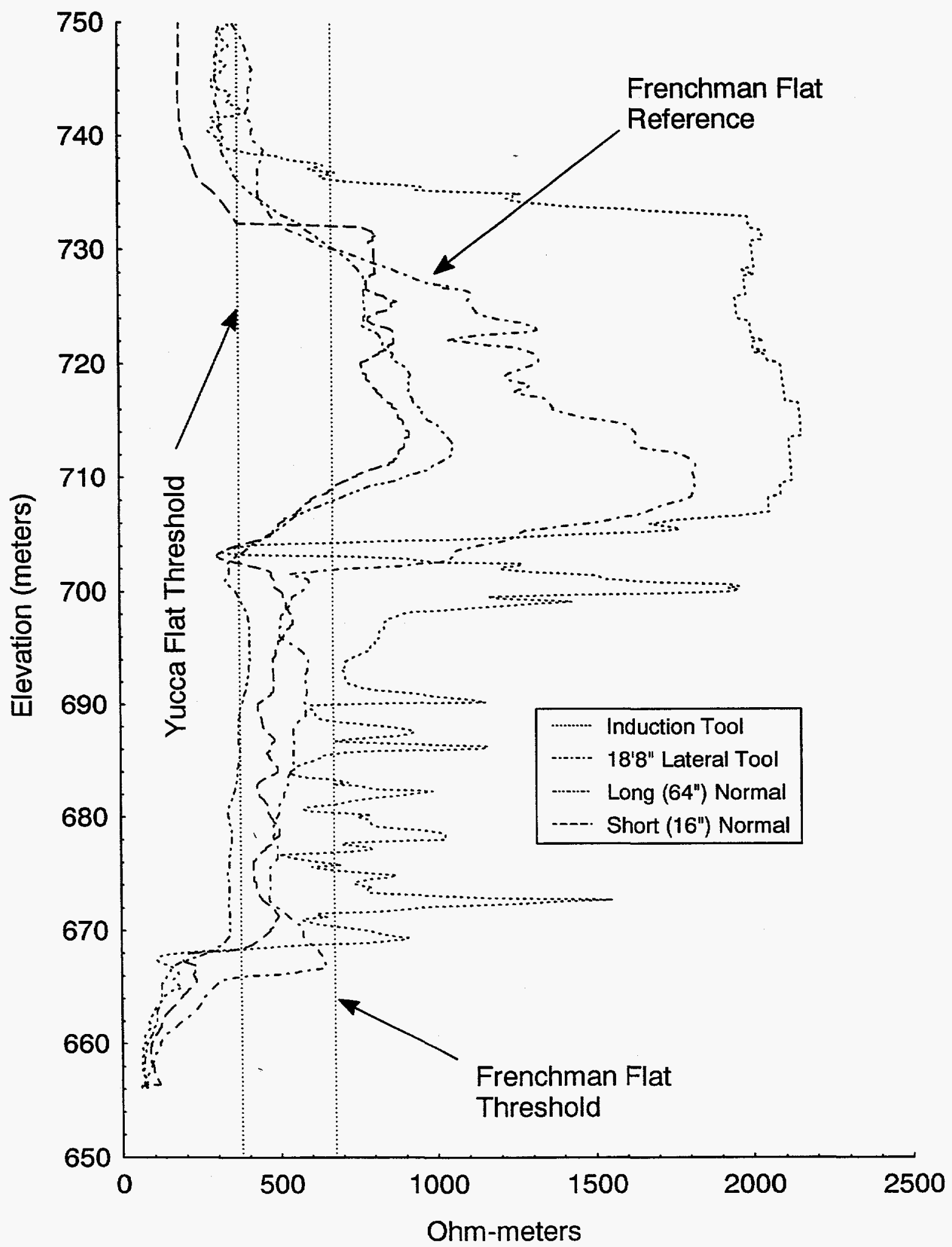

Figure 6. Short normal, long normal, $18 \mathrm{ft} 8$ in lateral, and induction tool resistivity curves. 


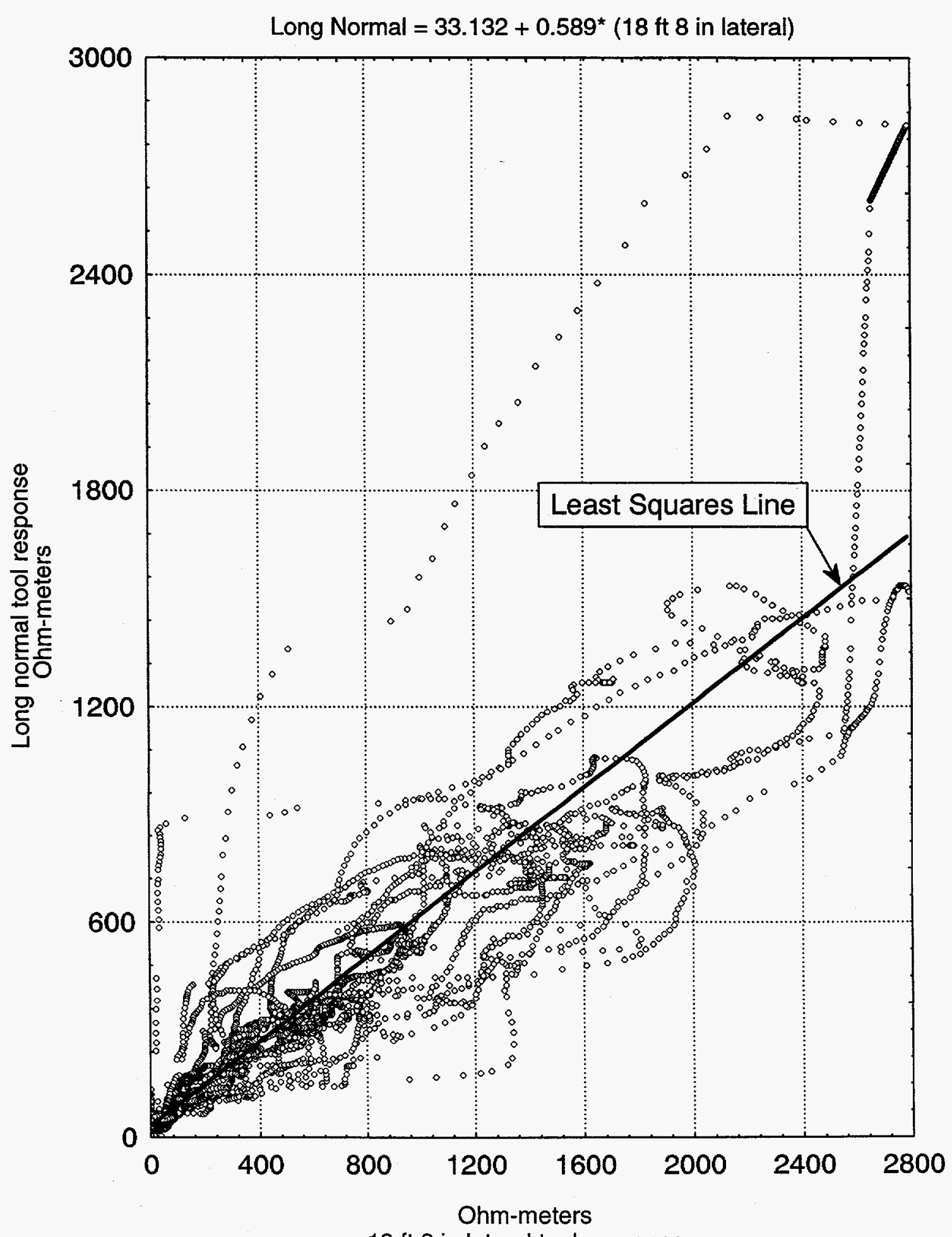

$18 \mathrm{ft} 8$ in lateral tool response

Figure 7. Scatterplot and regression line for resistivity measured by the long normal and $18 \mathrm{ft} 8 \mathrm{in}$ lateral tools. 
$2 \mathrm{~km}$ apart suggests either the basalt layer is on a single fault block or that minimal fault activity has taken place since emplacement in middle Miocene time." No lineaments were identified as entering or crossing the study area in the 1993 report by Miller, Gustafson and Synder, indicating that any faulting present in the study predates the development of the present geomorphic surface.

Assuming that the study area is not faulted is a conservative assumption which maintains lateral continuity in the lithostratigraphy. If there are high angle normal or reverse faults in the study area, then highly welded and hydraulically conductive simple cooling units would be vertically offset. Such offset would juxtapose lower conductivity units with higher conductivity units, effectively reducing the likelihood of a contiguous high conductivity conduit. Therefore, in the absence of any data indicating faulting has offset the volcanic units, it is assumed that the study area is a single structural block.

Vertical and horizontal variograms were prepared for both the Frenchman Flat and Yucca Flat resistivity data using the GS-LIB software (Deutsh and Journel, 1992). Figure 8 shows that a periodic or "hole-effect" variogram persists at different resistivity thresholds for Frenchman Flat vertically oriented data.

The domain shown in Figure 3 was discretized into a regular grid of 114,400 nodes with 52 nodes in $\mathrm{x}$ (east) direction, 44 nodes in the $\mathrm{y}$ (north) direction, and 50 nodes in the $\mathrm{z}$ (stratigraphic

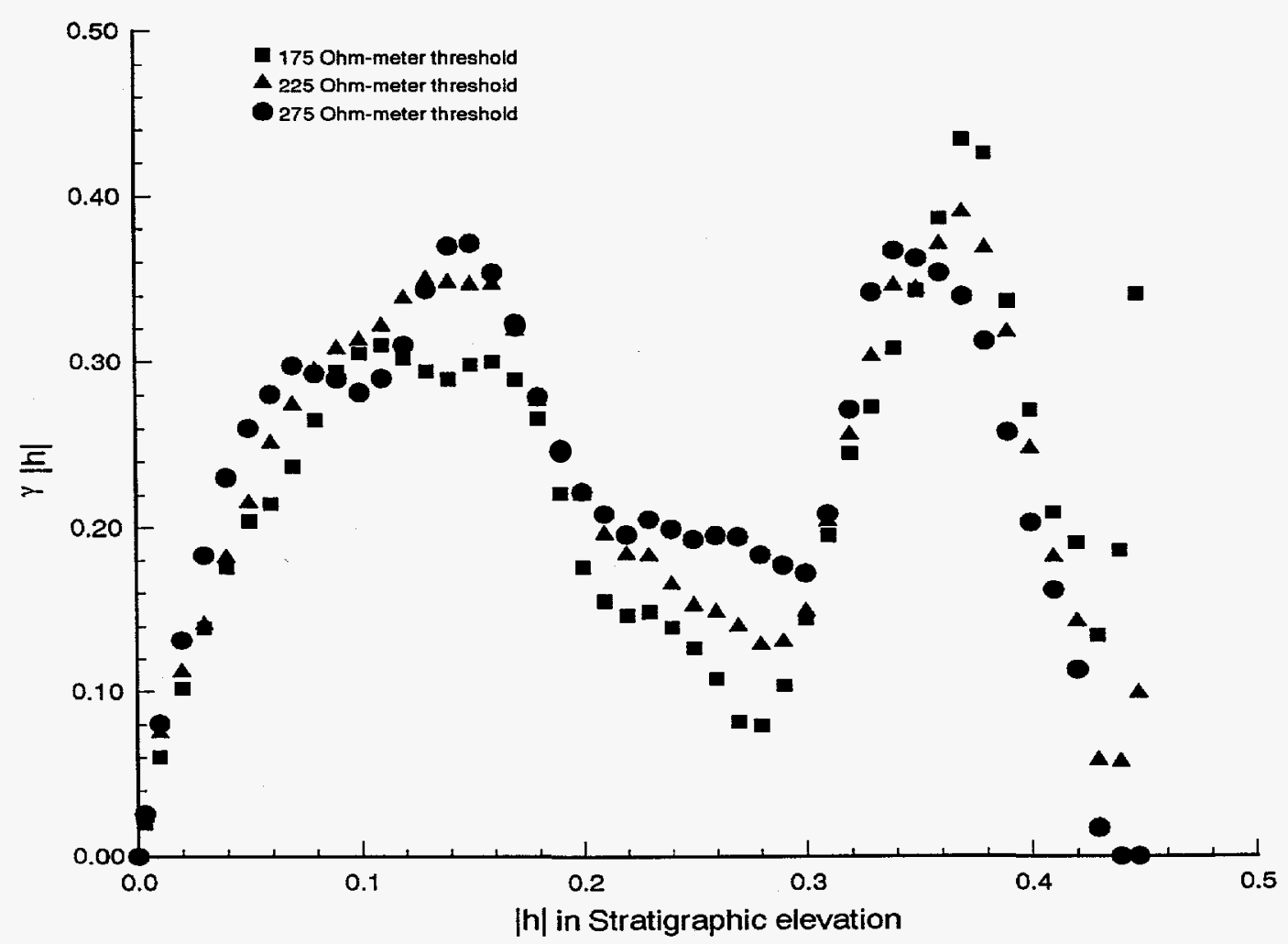

Figure 8. Vertical experimental semivariograms for Frenchman Flat resistivity data at three thresholds. 
depth) direction. Node spacing was $50 \mathrm{~m}$ in the $\mathrm{x}$ and $\mathrm{y}$ directions so the dimensions of the study area were 2550 by $2050 \mathrm{~m}$. Node spacing was 0.01 (stratigraphic coordinates) in the $\mathrm{z}$ dimension.

The equiprobable maps of subsurface heterogeneity at the Frenchman Flat CAU were generated using sequential indicator conditional simulation (SIS). For more detailed description of the procedure, the reader is referred to Pohlmann and Andricevic (1994). The methodology first uses the SIS algorithm to generate equiprobable maps of high resistivity tuff, inferred to have relatively high hydraulic conductivity. Maps of each realization are produced using three-dimensional scientific visualization programs (Tecplot $\odot$ and AVS $\odot$ ).

As described by Alabert (1987), the SIS algorithm estimates a value of the subsurface attribute at an unsampled location such that the new value is consistent with the inferred spatial correlation structure of that variable. The newly simulated value is then added to the existing data set (conditioning data) and the process is repeated. The original conditioning data include only the known data; but as the SIS simulation proceeds, the conditioning data set grows with the addition of each newly simulated data point. Therefore, the final simulated map honors the known data at their locations as well as the spatial correlation structure inferred from the known data set.

Using SIS, the values of the input data and simulated field are not continuous, but are assigned to classes which divide the total range of variability of the subsurface attribute. The classes are separated by threshold values that are chosen to divide the range of variability into meaningful classes. For example, hydraulic conductivity might be divided into three classes, such as low, medium, and high $\mathrm{K}$. In this case, the lower threshold value might be chosen such that the values of $\mathrm{K}$ in the lowest class might result in minimal flow. Likewise, the upper threshold might be chosen such that values of $\mathrm{K}$ in the highest class might result in significant groundwater flow velocities. The probability that a variable is in a particular class is determined by its indicator value. Indicators are a transform of the data values and represent the expected probability that the value of a variable at a particular location is less than or equal to the threshold value. The indicator has a value of one if the value of the variable is less than or equal to the threshold, and a value of zero if the value of the variable is greater than the threshold.

Thirty SIS simulations, labeled AA through $\mathrm{BD}$, were conducted using the computer program ISIM3D, a three-dimensional, multiple indicator, conditional simulation program developed by Gomez-Hernandez and Srivastava (1990). ISIM3D allows the use of both hard and soft data in the simulations of the hydrostratigraphic units. 


\section{RESULTS AND DISCUSSION}

Perspective views of four equiprobable maps (realizations) of the welded tuff units within the problem domain are shown in Figures 9 and 10. These zones represent nodes where the indicator value is simulated to be zero (i.e., where the resistivity value exceeds the threshold value). Zones simulated as non-welded tuff are not shown. These zones represent the nodes where the indicator value is simulated to be one (i.e., where resistivity values are below the threshold value). Extended regions of welded tuff suggest zones of preferred groundwater flow, while extended regions of non-welded tuff suggest potential barriers to groundwater flow. The hydrogeologic heterogeneity that is expected within natural geologic formations is clearly evident in these maps, with a considerable degree of connectivity of the welded tuff units apparent.

These maps show that welded tuffs are found in both isolated zones and as parts of large connected regions. Connected regions of welded tuffs extending horizontally from hundreds to thousands of meters are indicated. In contrast, the vertical connectivity of the welded tuffs is considerably less. This pattern, which is the consequence of the anisotropic covariance structure, illustrates the spatial anisotropy exhibited by volcanic tuff deposits (Istok et al., 1994).

The variation between maps illustrates the effect of data sparsity. Examination of the southeastern portion of the domain shows that the greatest variability is found where the least data were available. Traditional geologic cross sections fail to convey the fact that uncertainty increases with the distance from measurement.

Figures 11 and 12 show four realizations of zones where the hydraulic conductivity equals or exceeds $2.0 \mathrm{~m} /$ day. Continuous paths of relatively high conductivity cells in the model domain represent potential high-velocity conduits. Travel time for contaminants along these conduits will be significantly less than would be expected through more homogeneous media. 

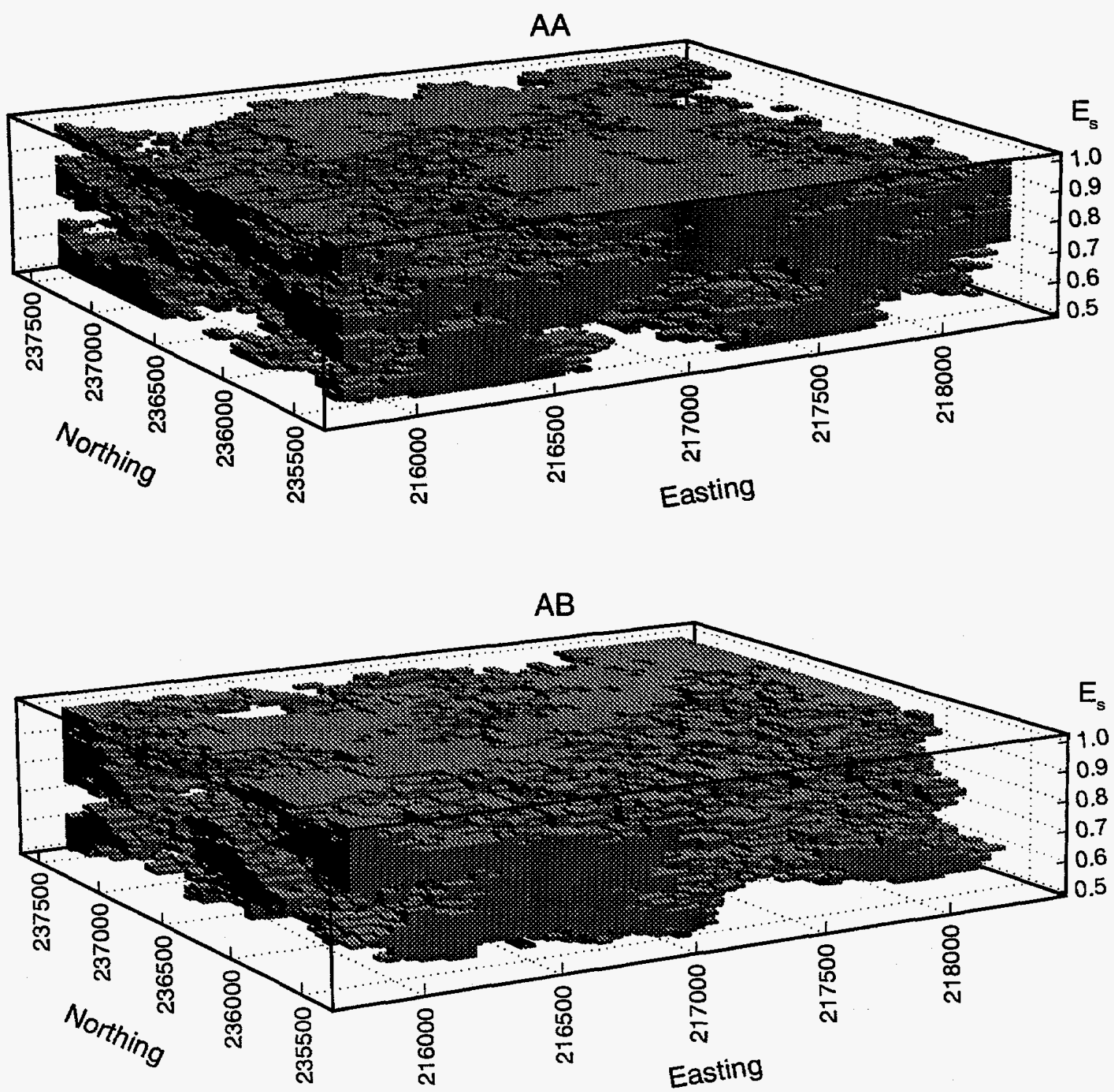

Figure 9. Realizations $A A$ and $A B$ of the welded tuff. 

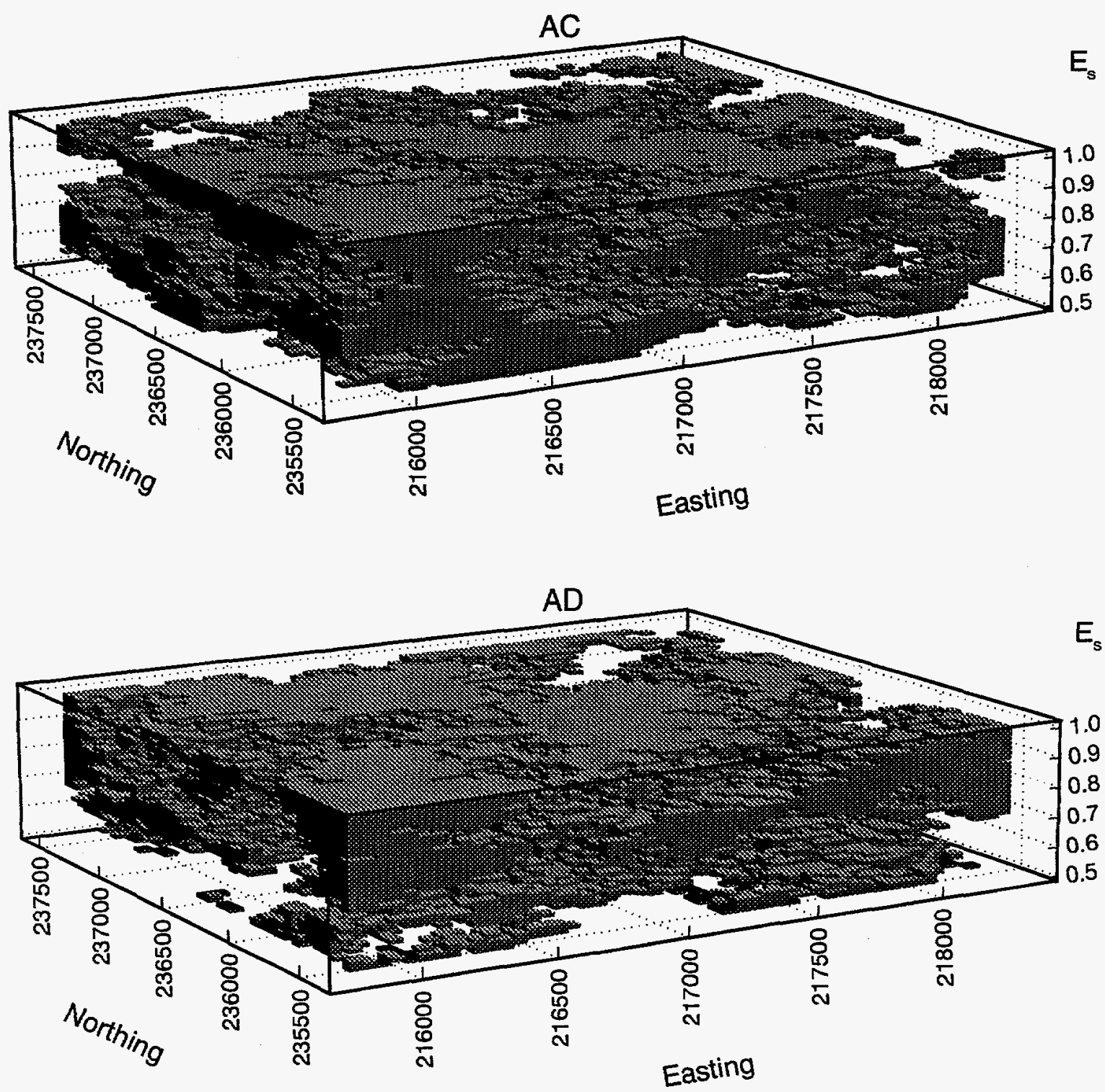

Figure 10. Realizations $\mathrm{AC}$ and $\mathrm{AD}$ of the welded tuff. 

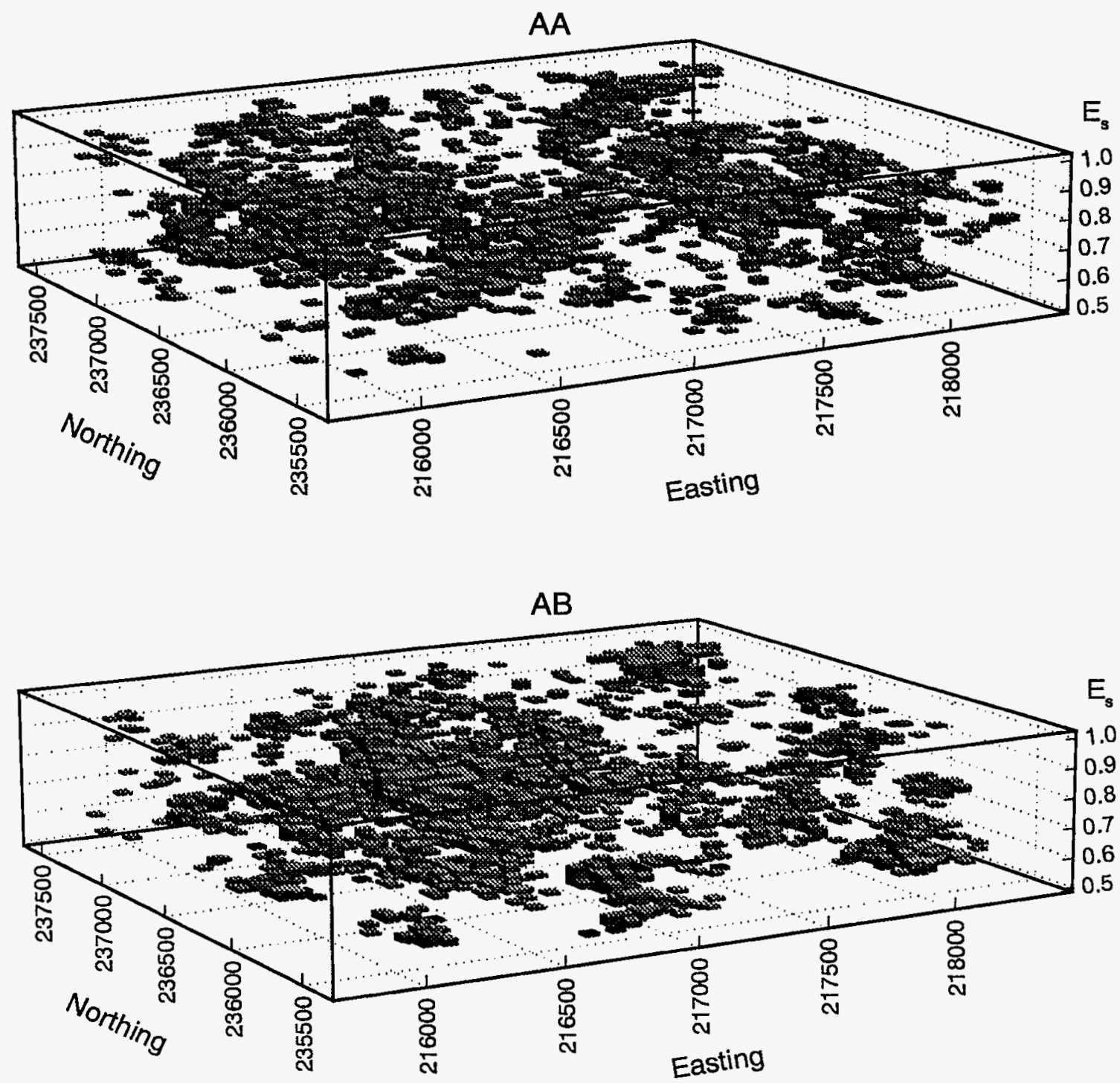

Figure 11. Realizations $\mathrm{AA}$ and $\mathrm{AB}$ of hydraulic conductivity equal to or greater than $2.0 \mathrm{~m} /$ day. 

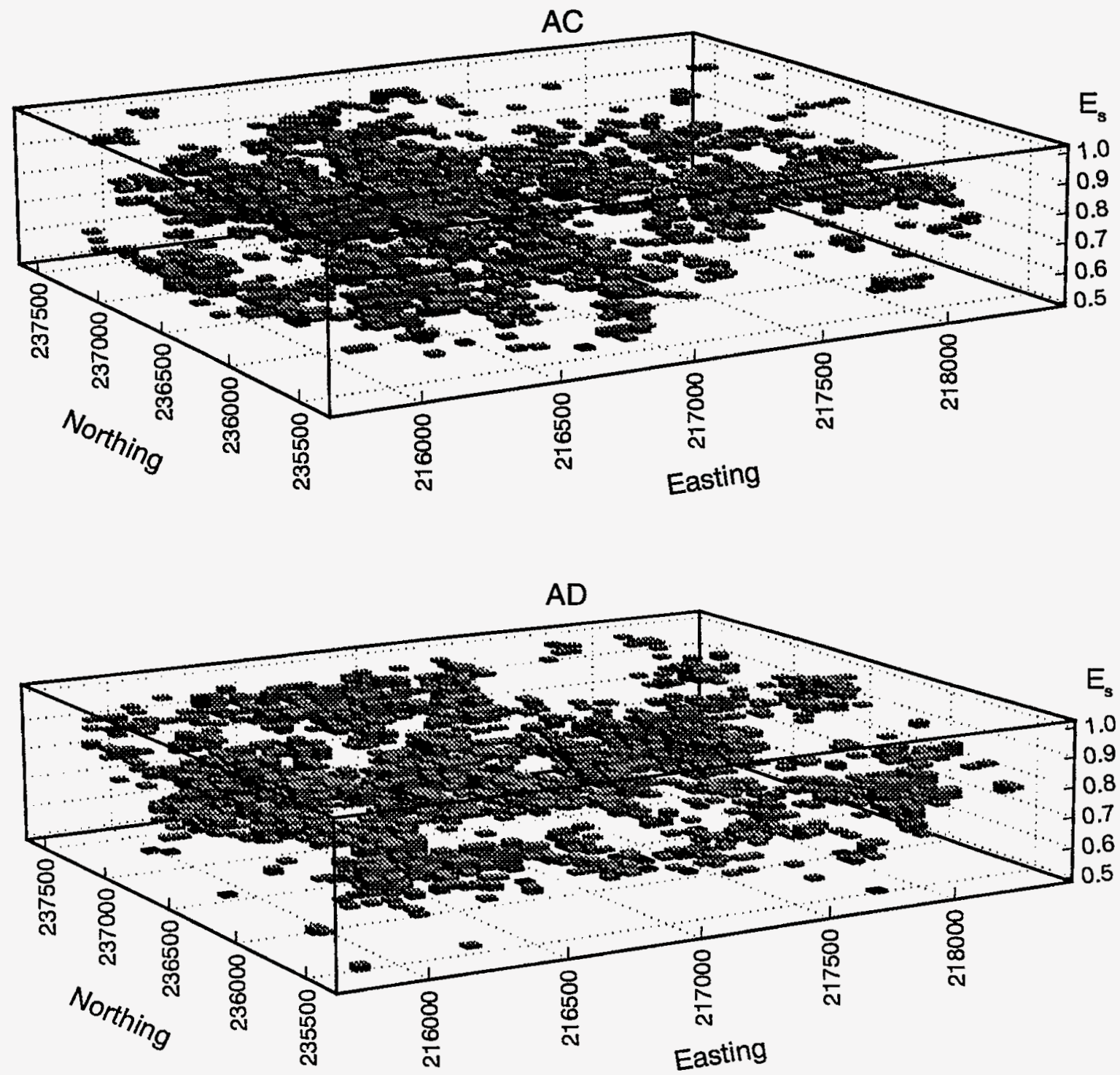

Figure 12. Realizations $\mathrm{AC}$ and $\mathrm{AD}$ of hydraulic conductivity equal to or greater than $2.0 \mathrm{~m} / \mathrm{day}$. 


\section{REFERENCES}

Alabert, A., 1987, Stochastic imaging of spatial distributions using hard and soft information. M.S. Thesis, Appl. Earth Sci. Dept., Stanford Univ., 184 pp.

Blankennagel, R.K. and J.E. Weir Jr., 1973. Geohydrology of the Eastern Part of Pahute Mesa, Nevada Test Site, Nye County, Nevada, U.S. Geological Survey Professional Paper 712-B, 35 pp.

Bloom, A.L., 1969, The Surface of the Earth, Prentice-Hall, Englewood Cliffs, New Jersey, 152 pp.

Bull, W.B., 1991, Geomorphic Responses to Climatic Change, Oxford University Press, New York, $326 \mathrm{pp}$.

Christiansen, R. L. and P.W. Lipman, 1972, Cenozoic Volcanism and Plate Tectonic Evolution of the Western United States, II, Late Cenozoic, Transactions of the Royal Society of London, Series A, v. 271 , pp. $249-284$

Collier, H.A., 1993, Borehole geophysical techniques for ground water and environmental investigations, National Ground Water Association Outdoor Action Conference, Las Vegas, NV, $423 \mathrm{pp}$.

Cressie, N.A., 1991, Statistics for Spatial Data, John Wiley \& Sons, New York, 900 pp.

Crowe, B.M., 1990, Basaltic volcanic episodes of the Yucca Mountain region, High Level Radioactive Waste Management, International Conference, p. 65-73

Crowe, B.M., K.H. Wohletz, D.T. Vaniman, E. Gladney and N.Bower, 1986, Status of volcanic hazard studies for the Nevada Nuclear Waste Storage Investigations, Los Alamos National Laboratory Report LA-9325-MS, v. II, 101 pp.

Crowe, B.M. and F.V. Perry, 1991, Preliminary geologic map of the Sleeping Butte Volcanic Centers, Los Alamos National Laboratory LA-12101-MS, 11 pp.

Deutsh, C.V. and A.G. Journel, 1992, GSLIB, Geostatistical Software Library and User's Guide, Oxford Univ. Press, $340 \mathrm{pp}$.

Drellack, S.L., 1994, An introduction to NTS geology and geophysical log characteristics, Ratheon Services Nevada, $68 \mathrm{pp}$.

Gomez-Hernandez, J.J. and R.M. Srivastava, 1990, ISIM3D, An ANSI-C three-dimensional multiple indicator conditional simulation program, Comp. \& Geo S., 16(4), 395-440.

Issaks, E.H. and R.M. Srivastava, 1989, An Introduction to Applied Geostatistics, Oxford University Press, New York, 561 pp.

Istok, J.D., C.A. Rautman, L.E. Flint and A.L. Flint, 1994, Spatial variability in hydrologic properties of a volcanic tuff, Ground Water, 32(5), 751-760.

Journel, A.G., 1989, Fundamentals of geostatistics in five lessons, Short course in Geology, Vol. 8, American Geophysical Union, 40 pp. 
Journel, A.G. and F.G. Alabert, 1990, Non-Gaussian data expansion in the Earth sciences, Terra Nova, 1(2), 123-134.

Miller, J.J., D.L. Gustafson and K.E. Synder, 1993, Lineaments identified in northern Frenchman Flat, Nye, Lincoln, and Clark Counties, Nevada, Scale 1:12,000, Raytheon Services Nevada, Las Vegas, NV

Miller, C.H. and D.L. Healy, 1986, Gavity Interpretation of Frenchman Flat and vicinity, Nevada Test Site, U.S. Geological Survey Open File Report 86-211, 36 pp, Denver, Colorado

Pohlmann, K.F. and R. Andricevic, 1994, Identification of potential groundwater flow paths using geological and geophysical data. Desert Research Institute, Water Resources Center, Publication \#45128, 23 pp.

Press, W.H., B.P. Flannery, S.A. Teukolsky and W.T. Vetterling, 1989, Numerical Recipes in Pascal, The art of scientific computing, Cambridge University Press, Cambridge, p. 107-109.

Rehfeldt, K., O. Drici, J. Renier and J. Marie, 1995, Hydraulic test parameter data task data documentation, IT Corporation, (unpublished draft).

Reynolds Electrical and Engineering Co., Inc., Special Projects Section, 1993a. Hydrogeologic Data for Science Trench Boreholes at the Area 5 Radioactive Waste Management Site, Nevada Test Site, Nevada. prepared for the U.S. Dept. of Energy, Nevada Operations Office, variable paging.

Reynolds Electrical and Engineering Co., Inc., Special Projects Section, 1993b. Site Characterization and Monitoring Data from Area 5 Pilot Wells, Nevada Test Site, Nevada. prepared for the U.S. Dept. of Energy, Nevada Operations Office, variable paging.

Seaber, P.R., 1992, Proposed Addition to the North American Code of Stratigraphic Nomeclature (unpublished draft).

Schlumberger, 1989, Log Interpretation Principles/Applications, Schlumberger Educational Services, Houston, Texas.

Shirley, C.T., 1995, Hydrostratigraphic units within the alluvium and tertiary volcanics of east central Yucca Flat, Nevada Test Site, M.S. Thesis, Department of Geosciences, University of Nevada, Las Vegas, $154 \mathrm{pp}$.

Synder, K.E., D.L. Gustafson, J.J. Miller and S.E. Rawlinson, 1994. Geologic components of site characterization and perfomance assessment for a radioactive waste management facility at the Nevada Test Site, DOE/NV/10833-20, UC 721, 12 pp.

Winograd, I.J., and W. Thordarson, 1975. Hydrogeologic and Hydrochemical Framework, South-Central Great Basin, Nevada-California, with Special Reference to the Nevada Test Site, U.S. Geological Survey Professional Paper 712-C, 126 p.

Wood, W. W., and L. A. Fernandez, 1988, The Geology of North America, Vol. O-2, Hydrogeology, p. 353-365. 


\section{DISTRIBUTION}

Bob Bangerter

Environmental Restoration Division

Nevada Operations Office

U.S. Department of Energy

P.O. Box 98518

Las Vegas, NV 89193-8518

Joanne M. Bradbery, Director

Contract Management Division

Nevada Operations Office

U.S. Department of Energy

P.O. Box 98518

Las Vegas, NV 89193-8518

David Bedsun

Defense Special Weapons Agency

Field Command

Nevada Operations Office

P.O. Box 208

Mercury, NV 89023-0208

Mary Lou Brown

International Technology Corporation

4330 S. Valley View

Suite 114

Las Vegas, NV 89103

James Cebe

Energy Technologies Division

Nevada Operations Office

U.S. Department of Energy

P.O. Box 98518

Las Vegas, NV 89193-8518

Frank Di Sanza, Director

Energy Technologies Division

Nevada Operations Office

U.S. Department of Energy

P.O. Box 98518

Las Vegas, NV 89193-8518

Brian Dozier

Bechtel Nevada Corporation

P.O. Box 98521

Las Vegas, NV 89193-8521
Doug Duncan

Hydrology Program Manager

Environmental Protection Division

Nevada Operations Office

U.S. Department of Energy

P.O. Box 98518

Las Vegas, NV 89193-8518

Dennis Farmer

Radiation Sciences Laboratory

Office of Radiation and Indoor Air

U.S. Environmental Protection Agency

P.O. Box 98517 , M/S 513

Las Vegas, NV 89193-8517

Larry Franks

Nevada State Health Department

Radiological Health Section

620 Belrose Avenue

Las Vegas, NV 89158

Joseph M. Ginanni

Waste Management Division

Nevada Operations Office

U.S. Department of Energy

P.O. Box 98518

Las Vegas, NV 89193-8518

Virginia Glanzman

U.S. Geological Survey

Box 2506, MS 913

Denver Federal Center

Denver, CO 80225

Kenneth Hoar, Director

Environmental Protection Division

Nevada Operations Office

U.S. Department of Energy

P.O. Box 98518

Las Vegas, NV 89193-8518

Roger Jacobson

Desert Research Institute

Water Resources Center

P.O. Box 19040

Las Vegas, NV 89132-0040 
Marjory Jones

Desert Research Institute

Water Resources Center

P.O. Box 60220

Reno, NV 89506-0220

Jim Kannard

Bechtel Nevada Corporation

P.O. Box 98521

Las Vegas, NV 89193-8521

Randy Laczniak

U.S. Geological Survey

Water Resources Division

6770 S. Paradise Rd.

Las Vegas, NV 89119

Steve Lawrence

Engineering Division

Nevada Operations Office

U.S. Department of Energy

P.O. Box 98518

Las Vegas, NV 89193-8518

Steve Leedom

Stockpile Stewardship Division

Nevada Operations Office

U.S. Department of Energy

P.O. Box 98518

Las Vegas, NV 89193-8518

Charles E. McWilliam, Director

Defense Projects Division

Nevada Operations Office

U.S. Department of Energy

P.O. Box 98518

Las Vegas, NV 89193-8518

Steve Mellington, Director

Environmental Restoration Division

Nevada Operations Office

U.S. Department of Energy

P.O. Box 98518

Las Vegas, NV 89193-8518
Leslie A. Monroe

Environmental Protection Division

Nevada Operations Office

U.S. Department of Energy

P.O. Box 98518

Las Vegas, NV 89193-8518

Kèn Rehfeldt

Geotrans, c/o IT

4330 Valley View

Suite 112, MS-439

Las Vegas, NV 89103

Stuart E. Rawlinson

Bechtel Nevada Corporation

P.O. Box 95487, M/S 580

Las Vegas, NV 89193-5487

Monica Salazar-Sanchez

Environmental Restoration Division

Nevada Operations Office

U.S. Department of Energy

P.O. Box 98518

Las Vegas, NV 89193-8518

Ralph Smiecinski

Energy Technologies Division

Nevada Operations Office

U.S. Department of Energy

P.O. Box 98518

Las Vegas, NV 89193-8518

David K. Smith

Isotopes Sciences Division

Lawrence Livermore National Laboratory

P.O. Box 808, M/S L231

Livermore, CA 94550

Michael J. Sully

Bechtel Nevada Corporation

P.O. Box 98521, M/S 966

Las Vegas, NV 98193-8521

Joe Thompson

Los Alamos National Laboratory

INC-11, MS J514

P.O. Box 1663

Los Alamos, NM 87545 
Doug Trudeau

U.S. Geological Survey

Water Resources Division

6770 S. Paradise Rd.

Las Vegas, NV 89119

Janet Wiley

International Technology Corporation

4330 S. Valley View

Suite 114

Las Vegas, NV 89103

Annie Kelley

State Documents Department

Nevada State Library

Capitol Complex

Carson City, NV 89710

Archives

Getchell Library

University of Nevada, Reno

Beverly Carter

MacKay School of Mines Library

University of Nevada, Reno

Document Section, Library

University of Nevada, Las Vegas

4505 Maryland Parkway

Las Vegas, NV 89154

Library (Stead)

Desert Research Institute

P.O. Box 60220

Reno, Nevada 89506-0220
Library

IT Corporation

4330 S. Valley View

Suite 114

Las Vegas, NV 89103

ATTN: Toni Miller

Library

Southern Nevada Science Center

Desert Research Institute

P.O. Box 19040

Las Vegas, NV 89132-0040

Public Reading Facility

Bechtel Nevada Corporation

P.O. Box 98521

Las Vegas, NV 89193-8521

Technical Information Resource Center

Nevada Operations Office

U.S. Department of Energy

P.O. Box 98518

Las Vegas, NV 89193-8518

Librarian

Water Resources Center Archives

$4100^{\circ}$ Brien Hall

University of California

Berkeley, CA 94720-1718

Office of Scientific and Technical Information

U.S. Department of Energy

P.O. Box 62

Oak Ridge, TN 37831-9939 